\title{
Principles of Natural Regeneration of Tropical Dry Forests for Restoration
}

\author{
Daniel L. M. Vieira ${ }^{1,2,3}$ and Aldicir Scariot ${ }^{2,4}$
}

\begin{abstract}
Tropical dry forests are the most threatened tropical terrestrial ecosystem. However, few studies have been conducted on the natural regeneration necessary to restore these forests. We reviewed the ecology of regeneration of tropical dry forests as a tool to restore disturbed lands. Dry forests are characterized by a relatively high number of tree species with small, dry, wind-dispersed seeds. Over small scales, wind-dispersed seeds are better able to colonize degraded areas than vertebrate-dispersed plants. Small seeds and those with low water content are less susceptible to desiccation, which is a major barrier for establishment in open areas. Seeds are available in the soil in the early rainy season to maximize the time to grow. However, highly variable precipitation and frequent dry spells are important sources of mortality in seeds and seedlings. Collecting seeds at the end of the dry season and planting them when soil has sufficient moisture may increase seedling establishment and reduce the time they
\end{abstract}

are exposed to seed predators. Germination and early establishment in the field are favored in shaded sites, which have milder environment and moister soil than open sites during low rainfall periods. Growth of established seedlings, however, is favored in open areas. Therefore, clipping plants around established seedlings may be a good management option to improve growth and survival. Although dry forests have species either resistant to fire or that benefit from it, frequent fires simplify community species composition. Resprouting ability is a noticeable mechanism of regeneration in dry forests and must be considered for restoration. The approach to dry-forest restoration should be tailored to this ecosystem instead of merely following approaches developed for moister forests.

Key words: assisting natural regeneration, coppice, seasonal forests, sprouting, tropical deciduous forests, tropical semideciduous forests.

\section{Introduction}

There are three reasons to review the ecology of natural regeneration in seasonally dry tropical forests (SDTFs). First, SDTFs, which originally represented $42 \%$ of the tropical vegetation worldwide (Murphy \& Lugo 1995), are the most threatened tropical terrestrial ecosystem, due to the conversion of these areas into agricultural land (Janzen 1988; Mooney et al. 1995; Khurana \& Singh 2001; Sanchez-Azofeifa et al. 2005). Thus, scientific knowledge, specifically regarding regeneration pathways, is crucial to the restoration of these forests. Second, there have been insufficient studies of SDTFs to date (Mooney et al. 1995; Khurana \& Singh 2001; Sanchez-Azofeifa et al. 2005). We found four to five times more studies on the natural regeneration of tropical rainforests than on the natural regeneration of dry forests, and only $3 \%$ of the literature on tropical forest restoration focuses on dry forests (Meli 2003). Third, SDTFs have particular natural regeneration

${ }^{1}$ Pós-Graduação em Ecologia, Universidade de Brasília, Caixa Postal 04457.

70919-970, Brasília, DF, Brazil.

${ }^{2}$ Laboratório de Ecologia e Conservação, Embrapa-Recursos Genéticos e Biotecnologia, Caixa Postal 02372, 70770-900, Brasília, DF, Brazil.

${ }^{3}$ Address correspondence to D. L. M. Vieira, e-mail dvieira@cenargen.embrapa.br

${ }^{4}$ United Nations Development Programme, SCN quadra 2, bloco A, Ed.

Corporate Financial Center, $7^{\circ}$ andar, CEP 70712-901 Brasília, DF, Brazil.

(C) 2006 Society for Ecological Restoration International attributes that need to be clarified. Although these regeneration characteristics can be limiting in certain situations, they can also be used to assist in the recovery of these forests. If these characteristics are not well understood, we risk using inappropriate strategies based on studies from moister tropical forests, where most of the studies on forest recovery are being developed (Meli 2003; but see Janzen 2002). For instance, treefall gaps, which are focal regeneration sites in moister tropical forests, can decrease the seedling survival in SDTFs even for light-demanding trees because of the extreme temperatures and low humidity (Gerhardt 1996a; Mclaren \& McDonald 2003a, $2003 b$ ). Resprouting after injury, on the other hand, is a widespread occurrence in SDTFs (Ewel 1980; Kammesheidt 1999; Kennard et al. 2002), which may be useful for restoration but has been poorly studied in tropical forests.

Several aspects of the ecology of SDTFs have been reviewed previously. A comprehensive review of SDTFs can be found in the book Seasonally Dry Tropical Forests (Bullock et al. 1995); distribution patterns and ecological characteristics are discussed by Murphy and Lugo (1986); and seed and seedling ecology in SDTF species are extensively reviewed by Khurana and Singh (2001). The aim of our study is to review the ecology of natural regeneration of SDTFs, focusing on how the available information can be used to facilitate the recovery of these forests in 
disturbed areas. Throughout this article, we compare dry forests to well-studied tropical moist or wet forests. Instead of exhaustively reviewing life histories and ecological processes, we focus on the traits of SDTF most relevant for restoration.

\section{Description of Seasonally Tropical Dry Forests}

SDTFs occur in tropical regions with several months of severe or absolute drought (Mooney et al. 1995). Tropical and subtropical dry forests (sensu Holdridge 1967; used by Murphy \& Lugo 1986) occur in frost-free areas where the mean annual biotemperature is above $17^{\circ} \mathrm{C}$, annual mean precipitation ranges from 250 to $2,000 \mathrm{~mm}$, and potential evaporation is greater than precipitation for a significant part of the year. They encompass everything from tall, semideciduous forests to scrubland vegetation dominated by cactus (Menaut et al. 1995; Murphy \& Lugo 1995; Sampaio 1995) and have been referred to by many different names in the literature (Murphy \& Lugo 1995). These forests are frequently connected to savannas because they occur under the same climatic conditions, although dry forests are often found in soils of higher fertility (Mooney et al. 1995; Pennington et al. 2000). Hence, generalizations about SDTFs are rare (Murphy \& Lugo 1986). Instead, they are most frequently included in broad discussions of tropical forests or savannas.

Tropical dry forests have 30-90 tree species (based on surveys of 1-3 ha), 10-40 m of canopy height, and $17-40 \mathrm{~m}^{2}$ /ha of basal area (which represents $50 \%$ of wet forests), although there is a great variation among sites (Murphy \& Lugo 1986). Tropical dry forests have 50-75\% of the net primary productivity of wet forests, because, even though both forests grow similarly in the wet season, dry forests decrease in growth or even stop growing during the dry season (Ewel 1980; Murphy \& Lugo 1986). Although SDTFs grow slower than wet forests, they can recover their relatively simple mature structure after disturbance more rapidly than wet forests, which have a more complex structure (Ewel 1980; Murphy \& Lugo 1986; Kennard 2002).

\section{Phenology}

The timing of seed dispersal is very predictable for SDTFs. Fleshy-fruit maturation is concentrated in the rainy season and wind-dispersed and gravity-dispersed fruits mature mostly in the dry season (Janzen 1967; Singh \& Singh 1992; Bullock 1995; Justiniano \& Fredericksen 2000; Griz \& Machado 2001). Although the dispersal of animaldispersed species occurs during the rainy season, most of these seeds remain dormant until the beginning of the next rainy season in seasonal forests (Frankie et al. 1974; Garwood 1983). Thus, there has been selection for early rainy season germination in seasonal forests (Garwood 1983; Marod et al. 2002) because it maximizes the length of the first rainy season for the seedling, potentially increasing growth and the probability of survival (see Garwood 1983 for a full discussion). However, highly variable precipitation and frequent dry spells are the major traits in SDTF regions (Blain \& Kellman 1991; Murphy \& Lugo 1995; Sampaio 1995). The arrival of consistent rainfall is unpredictable, and at the beginning of the rainy season there may be dry spells that last for as long as 2 weeks (see Blain \& Kellman 1991). Delays in the first rains and dry spells are strong sources of mortality by desiccation in seeds and recently germinated seedlings in SDTFs (Ray \& Brown 1995; Vieira 2002; McLaren \& McDonald 2003b; but see Blain \& Kellman 1991).

Collecting seeds at the end of the dry season and planting them when the soil has sufficient moisture in the rainy season may increase seedling establishment. These same guidelines must be considered when planting nurserygrown seedlings. Some studies simulated the absence of dry spells in dry forests by supplementing water to seeds and seedlings (Blain \& Kellman 1991; Gerhardt 1996b; McLaren \& McDonald 2003b). These studies were conducted including three, one, and four species respectively, and only one study found a positive relationship between water addition and seed germination and seedling survival (McLaren \& McDonald 2003b). However, seeding after the beginning of consistent rain during the rainy season is an experiment of applicable value for restoration that still has to be validated. Although this procedure may increase seed germination, seedlings will have less time to grow by the end of the rainy season. This method should be particularly important for restoring open areas, where seed and seedling desiccation are higher (Ray \& Brown 1995; Vieira 2002; McLaren \& McDonald 2003b). Furthermore, delaying artificial seed dispersal reduces the time that seeds are available to seed predators, which is another significant obstacle to seed germination and consequently to forest recovery (Nepstad et al. 1996; Holl \& Lulow 1997). If direct seeding proves successful for SDTF restoration, it would provide a relatively simple method because it demands only a few trips to collect a representative number of species, because seed dispersal is concentrated in the middle and end of the dry season, although understory and fleshy-fruit species disperse mostly in the rainy season. Additionally, most SDTF species produce dormant seeds (Baskin \& Baskin 1998), which facilitate seed storage ex situ. In contrast, most rainforest species do not have seed dormancy and are viable for only a few days (Baskin \& Baskin 1998).

\section{Seed Types, Seed Dispersal, and Seed Banks}

The higher proportion of wind-dispersed species is another feature that differentiates dry forests from moister forests (Gentry 1995). Within SDTFs, wind dispersal is found in $63 \%$ of canopy tree species in Bolivia (Justiniano \& Fredericksen 2000), $45 \%$ of tree species in Central Brazil (Figueiredo 2002), 33\% of species in northeast Brazil (Griz \& Machado 2001), and 30\% of tree species in Costa 
Rica (Frankie et al. 1974). In contrast, the tree assemblage in tropical wet and moist forests is dominated by vertebrate-dispersed species, and wind dispersal occurs in only $0-16 \%$ of tree species (Frankie et al. 1974; Howe \& Smallwood 1982; Morellato et al. 2000). Dry fruits with small, low-water content seeds are often associated with wind dispersal and thereby are also characteristics of SDTF species (Bullock 1995; Griz \& Machado 2001; Figueiredo 2002).

Small, wind-dispersed seeds, in contrast with animaldispersed seeds, are not strongly affected by fragmentation or hunting (Gillespie 1999; Janzen 2002). Wind-dispersed seeds arrive in higher density than vertebrate-dispersed seeds up to a few hundred meters from the source of propagules (Willson \& Crome 1989; Zimmerman et al. 2000; Cubiña \& Aide 2001). For instance, anemochoric seeds are 47 times more frequent than animal-dispersed seeds ( 3 vs. 141 seeds $\mathrm{m}^{-2}$ year $^{-1}$ ) in open pastures up to $250 \mathrm{~m}$ from the adjacent forest (Holl 1999). Thus, the lack of seed arrival in open areas, a major limitation for forest regeneration, is overcome at some level by wind-dispersed seeds. This high capacity of colonization has contributed to an over-representation of wind-dispersed species in some tropical pastures (Posada et al. 2000) and in some tropical and subtropical secondary forests (Finegan \& Delgado 2000; Marcano-Vega et al. 2002). On the other hand, trees or shrubs present in abandoned agricultural areas provide perches for birds and bats, increasing the number of vertebrate-dispersed seeds up to one hundred times relative to open areas (Willson \& Crome 1989; da Silva et al. 1996; Nepstad et al. 1996; Slocum \& Horvitz 2000). In addition, some species successfully colonize pastures by cattle or horse dispersal (Janzen 1981; Aide et al. 2000), whereas others do not colonize areas even after decades of secondary succession due to extinction or population reduction of seed dispersers (Aide et al. 2000; Marcano-Vega et al. 2002).

Small and low-water content seeds are less susceptible to desiccation in open areas, which is another major barrier for the survival of fleshy-fruit seeds, which generally have high water content, soft seed coats, and have low germination percentages in abandoned pastures (Holl 1999; Vieira 2002).

Although SDTFs have a high proportion of dry, winddispersed fruits compared to moister tropical forests, they still have many fleshy-fruited species (Gentry 1995; Justiniano \& Fredericksen 2000; Griz \& Machado 2001). Also, SDTFs have some large-seeded species, wind or animal dispersed (Figueiredo 2002), which generally have more limited dispersal (Westoby et al. 1996; Eriksson \& Jakobsson 1999; Henery \& Westoby 2001; Westoby et al. 2002). For these species, the obstacles to conservation and restoration known in rainforests remain important. However, even forest recovery based on a small pool of winddispersed species will likely facilitate colonization by other species (Toh et al. 1999; Otsamo 2000; Engel \& Parrotta 2001; Feyera et al. 2002; Fensham \& Butler 2004; but see
Parrotta 1995 and Kanowski et al. 2003, 2005 for a detailed analysis on the variability of the efficiency of nurse tree species on catalyzing forest regeneration).

Few species have seed banks in tropical forests in general (Garwood 1989; Skoglund 1992; Vázquez-Yanes \& Orozco-Segovia 1993) and in SDTFs in particular (Skoglund 1992; Teketay \& Ganstrom 1995; Cabin et al. 2002). Hence, autochthonous seed banks will rarely contribute to the regeneration of deforested tropical dry forest areas (Teketay \& Ganstrom 1995; Cabin et al. 2002; Janzen 2002). However, there is a high seed availability in the soil at the end of the dry season (see section on Phenology). Therefore, collecting this transient seed bank (i.e., litter and soil) from forested areas at the end of the dry season and disposing it onto degraded areas seems to be a promising strategy for dry forest restoration (Sampaio \& Scariot, unpublished data).

\section{Seed Predation}

For many tropical tree species, most of the seeds are preyed upon after dispersal (e.g., Osunkoya 1994; Asquith et al. 1997; Guariguata et al. 2000). Although pertinent literature is scarce, predation seems to prevent germination in SDTFs just as much as in moister forests (Hammond 1995; Vieira 2002). Some patterns on seed predation can be established from tropical moist and wet forest literature. The intensity of seed predation is highly dependent on the seed species (Osunkoya 1994; Holl \& Lullow 1997). Medium-sized seeds $(0.2-4 \mathrm{~g})$ are generally more susceptible to rodents because they are easier to find than very small seeds and are easier to manipulate than larger seeds (Price \& Jenkins 1986; Nepstad et al. 1990; Osunkoya 1994; but see Hammond 1995; Holl \& Lulow 1997 for different results). Small seeds are eaten mainly by insects, such as ants (Nepstad et al. 1990; Osunkoya 1994; Nepstad et al. 1996).

Seed predation is also affected by land use (secondary succession, Hammond 1995; logging, Forget et al. 2001; and pasture, Holl \& Lulow 1997). Less rodent abundance in pastures may result in less medium-sized seed predation than in forests (Jones et al. 2003; Meiners \& LoGiudice 2003). Seed predation by ants, on the other hand, results in higher predation of small seeds in pastures (Nepstad et al. 1990; Nepstad et al. 1996; Duncan \& Duncan 2000; Jones et al. 2003). In early successional sites, dense shrub cover and liana tangles provide habitats for rodents and can increase seed predation (Peña-Claros \& De Boo 2002).

Available literature only provides sufficient background to roughly predict the amount of seeds lost to predation because predation rates are highly variable among species, sites, and faunal assemblage. Restoration based on direct seeding could use this information by selecting seed types less susceptible to predation. Highly susceptible seeds can be buried or planted as seedlings or stem cuttings, rather than being disposed on the soil surface. In direct seeding experiments in a dry forest in Thailand, buried seeds 
were less predated by ants and suffered less desiccation than unburied seeds (Woods \& Elliott 2004). Also, if seed predators (mostly rodents) can be satiated by large seed quantities (Donaldson 1993; Forget et al. 1999; Curran \& Leighton 2000; Chauvet et al. 2004; Xiao et al. 2005), it may be possible to artificially satiate them using alternate (nongerminable) food sources such as peanuts together with direct seeding, to minimize their impact.

\section{Seed Germination and Seedling Establishment}

Seed germination and early seedling establishment are highly limited by water in dry tropical forests (Lieberman \& $\mathrm{Li}$ 1992; Marod et al. 2002; McLaren \& McDonald 2003a, $2003 b$ ). Shaded sites become safe sites because the shade counteracts the water limitation in low rainfall periods and reduces seed and seedling desiccation (Lieberman \& $\mathrm{Li}$ 1992; Ray \& Brown 1995; McLaren \& McDonald 2003b). Although many SDTF tree species need large canopy gaps to regenerate (Pinard et al. 1999; Dickinson et al. 2000), seed germination and early seedling establishment are constrained in open areas, even for light demanding species (Vieira et al., unpublished data; Gerhardt 1994; Ray \& Brown 1995; McLaren \& McDonald 2003b; Woods \& Elliot 2004). Grass cover in abandoned pastures enhanced the percentage of germination for six of the nine species that showed some germination in an SDTF of Central Brazil (Guarino 2004). Similarly, a study in dry forests of Jamaica found that the proportion of seeds that germinated in partially shaded ( $37 \%$ full light) or heavily shaded (6\% full light) plots was double than that in open plots (86\% full light) (McLaren \& McDonald 2003b). In the same experiment, seedling survival was enhanced three to four times in the shaded plots. However, the success of early seedling establishment decreases in extreme shading conditions in SDTFs (Fetene \& Feleke 2001; Marod et al. 2004), as happens in moister forests (Augspurger 1984; Osunkoya et al. 1992; Souza \& Válio 2001).

Plant cover can also enhance seed germination for species of tropical moister forests in abandoned pastures (Holl 1999), but it is very significant, even essential, for germination and initial seedling establishment in more seasonal environments. In wet regions, moisture is high regardless of the canopy openness, whereas in dry regions light availability and moisture conditions are negatively correlated (Belsky et al. 1993; Callaway \& Walker 1997; Holmgren et al. 1997). For instance, in the Amazonian rainforest, seed germination and seedling survival were higher in bare soil than in pasture, secondary, or mature forest for 5 out of 11 species and lower in bare soil than pasture only for one (Camargo et al. 2002). In an Australian rainforest, direct seeding of a pioneer tree species resulted in higher germination, seedling survival, and growth when grass and weeds were eliminated (Sun et al. 1995; Sun \& Dickinson 1996). However, interaction between precipitation, soil depth, and dominant species cover determines the facilitative or competitive role of plant cover (Aide \&
Cavelier 1994). In harsh habitats, plant cover successfully facilitates recruitment and growth (Belsky et al. 1993; Duncan \& Chapman 2003).

Whereas seed germination is higher under plant cover, seedling growth is reduced in these areas when compared to open areas during the rainy season or with supplemental water (Vieira et al., unpublished data; Rincon \& Huante 1993; Hammond 1995; Gerhardt 1996a). Seedlings growing in open areas reach the canopy faster and can develop into saplings and adults that will shade undesirable species, such as grasses in abandoned pastures or liana tangles in gaps generated by logging. Different requirements for germination, survival, and growth make management difficult. If germination and early establishment are favored by shade, and established seedlings are favored in open areas, the recommended management would be clipping undesired plants around established seedlings and saplings. Studies conducted in an SDTF in Ghana, for instance, found high tree-seedling density and diversity under pure stands of an aggressive pioneer shrub, and those seedlings had higher growth and survival rates after the shrubs were removed (Honu \& Dang 2000, 2002). This management strategy could be applicable to any type of plant cover, such as grasses and forbs in abandoned agricultural areas and lianas in felling gaps. Weeding around established seedlings is not an expensive management tool when compared to the total costs of common practices used to restore tropical forests, which frequently include seedling production, planting, and weeding (e.g., Parrotta \& Knowles 1999), or even the use of tree guards (Lai \& Wong 2005) or seedling fences (Holl \& Quiros-Nietzen 1999). Herbicide application together with manual weeding, for example, accounted for $20 \%$ of all implantation costs in a restoration project based on direct seeding in semideciduous forests of southeast Brazil (Engel \& Parrotta 2001). The cost of enriching (i.e., planting seedlings) forest fragments in southeast Brazil comes to U.S. $\$ 1,050.00 /$ ha and of controlling vines (i.e., clipping whole plots) totals U.S. $\$ 94.50$ / ha (Viana et al. 1997). Liberating commercial tree saplings from competition in felling gaps using manual clipping or herbicides costs U.S. \$1.00-2.30/gap (Pariona et al. 2003).

\section{Fire Resistance}

Fire is not a frequent natural disturbance in SDTFs (Janzen 2002; Eriksson et al. 2003). A high incidence of fire can convert dry forests to savanna-like formations (Rundel \& Boonpragob 1995; Menaut et al. 1995; Fensham et al. 2003). Many savanna, woodland, and open forest areas are a consequence of crop cultivation followed by fire in originally seasonally dry forests in Africa (Hopkins 1992; Swaine 1992), Southeast Asia (Blasco 1983), southwest and the seasonal southeastern coastal planes of Papua New Guinea (Gillison 1983), and most likely northern Australia mediated by Aborigines (Gillison 1983). Fire eliminates species that are common in undisturbed environments and favors fire-resistant 
dry forest species (Goldammer 1993; Gillespie et al. 2000) and fire-tolerant trees that come from adjacent savannas (Hopkins 1992), both capable of regeneration by vegetative means (Blasco 1983; Goldammer 1993; Fensham et al. 2003; Saha \& Howe 2003). Grasses benefit by recurrent fires (D'Antonio \& Vitousek 1992; Hopkins 1992) and outcompete tree seedlings (Blasco 1983). Dry forests can naturally regenerate only by preventing fire in abandoned pastures (Janzen 2002) or anthropogenic savanna formations (Hopkins 1992).

These statements are confirmed by a few surveys and experimental studies of natural regeneration. Seed banks decreased by $93 \%$ in seed density and $81 \%$ in richness one day after a fire at a slash-and-burn site in a tropical deciduous forest in Mexico (Miller 1999). Nearly all (94\%) of the viable seeds died after high intensity burn treatments in Bolivian deciduous forests (Kennard et al. 2002). Experimental low-intensity fires over 2 years decreased seedling diversity by $30 \%$ in burned plots (Saha \& Howe 2003). In Thailand, a single fire event killed all seedlings from two out of six tree seedling species and resulted in variable resprouting of the others (Marod et al. 2004).

However, dry forests experience fires because they are often adjacent to savannas. There is a considerable overlap of species between savannas and dry forests, which grants the SDTF a certain fire resistance because savanna species are adapted to fire (Eriksson et al. 2003). Also, because agriculture, especially pastureland with exotic grasses, is expanding and interacting with SDTFs, fires have increased in frequency over the last centuries (D'Antonio \& Vitousek 1992; Khurana \& Singh 2001). Some species emerge quickly after fires (Marod et al. 2002) or even require fire to break dormancy (reviewed in Khurana \& Singh 2001). Although relative resistance to fire is helpful, because anthropogenic fires are one of the concerns of tropical forest conservation, frequent fire will ultimately simplify community composition to include only species resistant to it. Seedling survival following fire is discussed in the next section.

\section{Resprouting after Disturbance}

Many studies have indicated that seed dispersal, seed predation, seed desiccation, and seedling survival (reviewed in Holl 2002) are strong bottlenecks that prevent tropical forest recovery in abandoned agricultural areas. Resprouting after disturbances, such as slash and burn, is a shortcut for forest recovery because it eliminates the most vulnerable life stages, starting as a vigorous shoot (Miller \& Kauffman 1998; Kammesheidt 1999; Bond \& Midgley 2001; Kennard et al. 2002). However, species lose resprouting ability after sequential cutting, fire, and intensive tractor use (Uhl et al. 1988; de Rouw 1993; Sampaio et al. 1993; Nepstad et al. 1996). Moreover, some species are weak sprouters or do not sprout at all (Bond \& Midgley 2001; Vesk \& Westoby 2004).
There is a perception that sprouting ability is more common and more important as a mechanism of regeneration in SDTFs than in rainforests (Ewel 1980; Murphy \& Lugo 1986; Russell-Smith 1996; Kennard 2002; McLaren \& McDonald 2003c). In a recent attempt to compare resprouting ability across various vegetation types following heavy disturbance (i.e., fires resulting in stem kill), Vesk and Westoby (2004) found a higher percentage of nonsprouters in rainforests (data from one study) than in deciduous plus semideciduous forests (three studies). The reasons for the greater importance of resprouting in SDTFs than in moister forests are not certain. Ewel (1980) argues that seeds have a lower probability of establishment and that trunk bases are less subjected to decay. Another possibility is that SDTF plants are adapted for aboveground mortality or drought (Sampaio et al. 1993; Bond \& Midgley 2001).

Some studies have demonstrated the amazing resprouting ability after disturbance of SDTF species (McLaren \& McDonald 2003c, in Jamaica; Kennard et al. 2002, in Bolivia; Vieira et al. in press, in Brazil). McLaren and McDonald (2003c) cut stems $\geq 2 \mathrm{~cm}$ (diameter at breast height $[\mathrm{dbh}]$ ) at $50 \mathrm{~cm}$ in height, and 14 months later they verified coppice shoots in 48 of the 51 sampled species ( $81 \%$ average). In gaps managed by highintensity fire, $60 \%$ of individuals greater than $2.5 \mathrm{~m}$ tall after 18 months originated from sprouts, whereas in the control gap, plant removal treatment, and low-intensity burn treatment, sprouting contributed to $90 \%$ of all sampled individuals (Kennard et al. 2002). Recently plowed pastures that had been managed for up to 25 years in central Brazil held $42 \pm 15$ tree stems $/ 100 \mathrm{~m}^{2}($ mean $\pm \mathrm{SD})$ and $11.8 \pm 2.5$ root sucker species $/ 100 \mathrm{~m}^{2}$ (total $=39$ species in 0.3 ha) (Vieira et al. in press). The richness of root suckers is $20 \%$ lower than that of the tree species (stems $>5 \mathrm{~cm} \mathrm{dbh)} \mathrm{in} \mathrm{adjacent} \mathrm{intact} \mathrm{forests} \mathrm{(Scariot} \mathrm{\&}$ Sevilha 2000).

Although these are optimistic results, a multitude of factors influence the percentage of species that sprout and the relative contribution of sprouting to forest recovery, such as intensity, frequency, and type of disturbance. Resprouting ability varies among tree species (Sampaio et al. 1993; Kammasheidt 1999; McLaren \& McDonald 2003c), and it is currently impossible to generate models to predict the amount of species and individuals able to resprout (Bond \& Midgley 2001; Vesk \& Westoby 2004). Most clades have both strong sprouter and nonsprouter species, and this trait is not preserved along phylogenetic lineages (Vesk \& Westoby 2004). Vieira et al. (in press) maintain that hardwood species are better sprouters because their roots and stems have slower decay than softwood species. The slow decay rate was also a reason given for greater resprouting in dry forests than in rainforests (Ewel 1980). Species with high root starch concentrations, specifically carbohydrates, and species with high root to shoot ratios are also strong resprouters (Bond \& Midgley 2001). There is still much speculation on this topic, but it is essential for 
understanding the traits or identities of strong sprouters to be able to (1) use branch cuttings of these species as nurse trees in restoration plans; (2) invest in restoration of weak or nonsprouter species in early successional forests dominated by resprouters; and (3) help understand present and future community composition (Kennard 2002; Saha \& Howe 2003).

Considering that sprouting ability is positively related to branch cutting success (Itoh et al. 2002), using branch cuttings to improve SDTF recovery would be recommended (see also Sabogal 1992). The rooting ability of branch cuttings was tested, with relative success, for tropical rainforests in Malaysia (Itoh et al. 2002). Stems of live fence species $200 \mathrm{~cm}$ in height are being successfully tested to restore rainforests in Honduras (Zahawi 2005). Root cuttings taken from fallen trees of deforestation areas should also be tested for SDTF restoration because planting them is equivalent to root suckering after plowing (Vieira et al. in press). We also suggest evaluating the use of plowing to restore forests in pastures, which could temporarily eliminate grasses and permit the resprouting of tree roots (Vieira et al. in press).

\section{Conclusions and Recommendations}

This article showed that the procedures for seasonal dry tropical forest restoration have to be tailored to this ecosystem, instead of following a formula developed for moister forests. The high proportion of small seeded, wind-dispersed species, the high ability of sprouting after disturbance, and the relatively simple community diversity and structure all confer a high potential for SDTFs recovery (Table 1). The guidelines proposed here are based on the ecology of natural regeneration and have not been fully tested as tools for management. Each site in each region will have its own set of suitable management strategies. Available budget and other logistic limitations must also be taken into account to select the best tools to restore each forest. Because of economic limitations for the conservation of tropical forests, assisting natural regeneration seems the most reliable option (Hardwick et al. 1997; Honu \& Dang 2002).

Future research should focus on developing and testing methods of vegetative propagation for SDTF restoration. Studies testing different types of plant cover on seed germination and early seedling development in the field are

Table 1. Natural regeneration characteristics of seasonally dry tropical forests, their contrasts with rainforests and restoration strategies, and/or aspects to consider in restoration planning.

\begin{tabular}{|c|c|c|c|}
\hline $\begin{array}{l}\text { Natural } \\
\text { Regeneration } \\
\text { Aspects }\end{array}$ & Dry Forests & Contrast with Rainforests & $\begin{array}{l}\text { Restoration Strategies/Aspects } \\
\text { to Consider in Restoration Planning }\end{array}$ \\
\hline Phenology & $\begin{array}{l}\text { Dispersal of dry seeds concentrated } \\
\text { at the end of the dry season, } \\
\text { fleshy fruits in the wet season, } \\
\text { with germination at the beginning } \\
\text { of the next rainy season }{ }^{d-j}\end{array}$ & $\begin{array}{l}\text { Seed dispersal not strongly } \\
\text { seasonal }^{i, k}\end{array}$ & $\begin{array}{l}\text { Seeds can be collected and kept } \\
\text { until better moisture conditions }\end{array}$ \\
\hline $\begin{array}{l}\text { Seed types, } \\
\text { dispersal, and } \\
\text { seed banks }\end{array}$ & $\begin{array}{l}\text { Relatively high proportion of dry } \\
\text { fruits and seeds, and } \\
\text { wind-dispersed dormant seeds } \\
g-i, l-n\end{array}$ & $\begin{array}{l}\text { Mostly fleshy fruits and } \\
\text { recalcitrant seeds }\end{array}$ & $\begin{array}{l}\text { Wind-borne seeds disperse easily } \\
\text { into adjacent open areas } \\
\text { Potential for storage of dormant seeds } \\
\text { Still have a high proportion of } \\
\text { vertebrate-dispersed seeds that } \\
\text { need to be considered }\end{array}$ \\
\hline Fire resistance & $\begin{array}{l}\text { Fire is not a natural frequent } \\
\text { disturbance. Some species } \\
\text { regenerate after fire }{ }^{a h-a j}\end{array}$ & Species less resistant to fire ${ }^{a k}$ & $\begin{array}{l}\text { Protection from fire helps forest } \\
\text { succession }^{a m}\end{array}$ \\
\hline $\begin{array}{l}\text { Resprouting } \\
\text { ability }\end{array}$ & $\begin{array}{l}\text { High proportion of strong } \\
\text { resprouter species }{ }^{b, c, a m}\end{array}$ & $\begin{array}{l}\text { Apparently lower proportion } \\
\text { of resprouter species }\end{array}$ & $\begin{array}{l}\text { Consider resprouting in restoration } \\
\text { strategies } \\
\text { Test the use of cuttings }\end{array}$ \\
\hline
\end{tabular}

(1992); ${ }^{a i}$ Blasco (1983); ${ }^{a j}$ Gillison (1983); ${ }^{a k}$ Goldammer (1993); ${ }^{a l}$ Janzen (2002); ${ }^{a m}$ McLaren \& McDonald (2003c); ${ }^{a n}$ Vesk \& Westoby (2004). 
necessary to accomplish restoration goals. Most studies are carried out in nursery conditions, testing water supplementation in two or three very contrasting light levels. Most management strategies recommended in this study are applicable only for part of the community; each species should thus be evaluated for the suitability of the proposed management. Species that are not expected to benefit from existing management strategies deserve special attention.

This study is a first attempt to fulfill the demand for research into dry forest restoration (Sanchez-Azofeifa et al. 2005). Before long, we expect that more studies will be available and that future research regarding this highly variable ecosystem will develop. Deciduousness, biomass, and other structural parameters, as well as abiotic aspects such as soil fertility, total precipitation, size and strength of the dry season, and its interactions with temperature, could be used to narrow the scope of a future review, which would generate more definitive and useful recommendations for restoration.

\section{Acknowledgments}

The ideas presented in this study evolved over a period of 4 years of discussing papers at the Laboratório de Ecologia e Conservação (Embrapa-Cenargen, Brasília), coordinated by A. Scariot and A. Sevilha. We are grateful for the useful discussions with A. Sampaio, A. Sevilha, and field assistants. An earlier version was written during a quarter at the University of California, Santa Cruz, when D. Vieira received a fellowship from the Center for Tropical Ecology, Agriculture and Development (http://cen tread.ucsc.edu). K. Holl, G. Gilbert, and their students encouraged and significantly improved the quality of this article at that time. J. Kanowski and two anonymous reviewers fine-tuned the quality of the manuscript and our knowledge of the restoration ecology literature. J. Haring, I. Figueiredo, B. Baker, and Scott helped with English editing. CAPES has provided D. Vieira with a doctorate fellowship.

\section{LITERATURE CITED}

Aide, T. M., and J. Cavelier. 1994. Barriers to lowland tropical forest restoration in the Sierra Nevada de Santa Marta, Colombia. Restoration Ecology 2:219-229.

Aide, T. M., J. K. Zimmerman, J. B. Pascarella, L. Rivera, and H. MarcanoVega. 2000. Forest regeneration in a chronosequence of tropical abandoned pastures: implications for restoration ecology. Restoration Ecology 8:328-338.

Asquith, N. M., S. J. Wright, and M. J. Clauss. 1997. Does mammal community composition control recruitment in neotropical forests? Evidence from Panama. Ecology 78:941-946.

Augspurger, C. K. 1984. Light requirements of neotropical tree seedlings: a comparative study of growth and survival. Journal of Ecology 72:777-795.
Baskin, C. C., and J. M. Baskin. 1998. Seeds: ecology, biogeography, and evolution of dormancy and germination. Academic Press, San Diego, California.

Belsky, A. J., S. M. Mwonga, R. G. Amundson, J. M. Duxbury, and A. R. Ali. 1993. Comparative effects of isolated trees on their undercanopy environments in high-rainfall and low-rainfall savannas. Journal of Applied Ecology 30:143-155.

Blain, D., and M. Kellman. 1991. The effect of water-supply on tree seedgermination and seedling survival in a tropical seasonal forest in Veracruz, Mexico. Journal of Tropical Ecology 7:69-83.

Blasco, F. 1983. The transition from open forest to savanna in continental Southeast Asia. Pages 167-181 in F. Bourlière, editor. Tropical savannas. Elsevier, Amsterdam, the Netherlands.

Bond, W. J., and J. J. Midgley. 2001. Ecology of sprouting in woody plants: the persistence niche. Trends in Ecology and Evolution 16:45-51.

Bullock, S. H. 1995. Plant reproduction in neotropical dry forests. Pages 277-303 in S. H. Bullock, H. A. Mooney, and E. Medina, editors. Seasonally dry tropical forests. Cambridge University Press, New York.

Bullock, S. H., H. A. Mooney, and E. Medina. 1995. Seasonally dry tropical forests. Cambridge University Press, New York.

Cabin, R. J., S. G. Weller, D. H. Lorence, S. Cordell, and L. J. Hadway. 2002. Effects of microsite, water, weeding, and direct seeding on the regeneration of native and alien species within a Hawaiian dry forest preserve. Biological Conservation 104:181-190.

Callaway, R. M., and L. R. Walker. 1997. Competition and facilitation: a synthetic approach to interactions in plant communities. Ecology 78:1958-1965.

Camargo, J. L. C., I. D. K. Ferraz, and A. M. Imakawa. 2002. Rehabilitation of degraded areas of central Amazonia using direct sowing of forest tree seeds. Restoration Ecology 10:636-644.

Chauvet, S., F. Feer, and P.-M. Forget. 2004. Seed fate of two Sapotaceae species in a Guianan rain forest in the context of escape and satiation hypotheses. Journal of Tropical Ecology 20:1-9.

Cubiña, A., and T. M. Aide. 2001. The effect of distance from forest edge on seed rain and soil seed bank in a tropical pasture. Biotropica 33:260-267.

Curran, L. M., and M. Leighton. 2000. Vertebrate responses to spatiotemporal variation in seed production of mast-fruiting dipterocarpaceae. Ecological Monographs 70:101-128.

D'Antonio, C. M., and P. M. Vitousek. 1992. Biological invasions by exotic grasses, the grass/fire cycle, and global change. Annual Review of Ecology and Systematics 23:63-87.

da Silva, J. M. C., C. Uhl, and G. Murray. 1996. Plant succession, landscape management, and the ecology of frugivorous birds in abandoned Amazonian pastures. Conservation Biology 10:491-503.

de Rouw, A. 1993. Regeneration by sprouting in slash and burn rice cultivation, Taï Rain Forest, Côte d'Ivoire. Journal of Tropical Ecology 9:387-408.

Dickinson, M. B., D. F. Whigham, and S. M. Hermann. 2000. Tree regeneration in felling and natural treefall disturbances in a semideciduous tropical forest in Mexico. Forest Ecology and Management 134: $137-151$.

Donaldson, J. S. 1993. Mast-seeding in the Cycad genus Encephalartos: a test of the predator satiation hypothesis. Oecologia 94: 262-271.

Duncan, R. S., and C. A. Chapman. 2003. Consequences of plantation harvest during tropical forest restoration in Uganda. Forest Ecology and Management 173:235-250.

Duncan, R. S., and V. E. Duncan. 2000. Forest succession and distance from forest edge in an Afro-tropical grassland. Biotropica 32:33-41.

Engel, V. L., and J. A. Parrotta. 2001. An evaluation of direct seeding for reforestation of degraded lands in central Sao Paulo state, Brazil. Forest Ecology and Management 152:169-181. 
Eriksson, I., D. Teketay, and A. Granstrom. 2003. Response of plant communities to fire in an Acacia woodland and a dry Afromontane forest, southern Ethiopia. Forest Ecology and Management 177: $39-50$.

Eriksson, O., and A. Jakobsson. 1999. Recruitment trade-offs and the evolution of dispersal mechanisms in plants. Evolutionary Ecology 13:411-423.

Ewel, J. 1980. Tropical succession: manifold routes to maturity. Biotropica 12:2-7.

Fensham, R. J., and D. W. Butler. 2004. Spatial pattern of dry rainforest colonizing unburnt Eucalyptus savanna. Austral Ecology 29: $121-128$.

Fensham, R. J., R. J. Fairfax, D. W. Butler, and D. M. J. S. Bowman. 2003. Effects of fire and drought in a tropical eucalypt savanna colonized by rain forest. Journal of Biogeography 30:1405-1414.

Fetene, M., and Y. Feleke. 2001. Growth and photosynthesis of seedlings of four tree species from a dry tropical Afromontane forest. Journal of Tropical Ecology 17:269-283.

Feyera, S., E. Beck, and U. Luttge. 2002. Exotic trees as nurse-trees for the regeneration of natural tropical forests. Trees-Structure and Function 16:245-249.

Figueiredo, I. B. 2002. Padrões de polinização e dispersão de sementes de espécies arbóreas de floresta estacional decidual, Brasil Central. Bachelor Monograph, UNESP, Instituto de Biociências, Rio Claro, SP, Brazil.

Finegan, B., and D. Delgado. 2000. Structural and floristic heterogeneity in a 30-year-old Costa Rican rain forest restored, on pasture through natural secondary succession. Restoration Ecology 8: 380-393.

Forget, P.-M., K. Kitajima, and R. B. Foster. 1999. Pre- and post-dispersal seed predation in Tachigali versicolor (Caesalpiniaceae): effects of timing of fruiting and variation among trees. Journal of Tropical Ecology 15:61-81.

Forget, P.-M., J. M. Rankin-De Merona, and C. Julliot. 2001. The effects of forest type, harvesting and stand refinement on early seedling recruitment in a tropical rain forest. Journal of Tropical Ecology 17:593-609.

Frankie, G. W., H. G. Baker, and P. A. Opler. 1974. Comparative phenological studies of trees in tropical wet and dry forests in lowlands of Costa-Rica. Journal of Ecology 62:881-919.

Garwood, N. C. 1983. Seed germination in a seasonal tropical forest in Panama: a community study. Ecological Monographs 53:159-181.

Garwood, N. C. 1989. Tropical seed banks: a review. Pages 149-208 in M. A. Leck, V. T. Parker, and R. L. Simpson, editors. Ecology of soil seed banks. Academic Press, San Diego, California.

Gentry, A. H. 1995. Diversity and floristic composition of neotropical dry forests. Pages 145-194 in S. H. Bullock, H. A. Mooney, and E. Medina, editors. Seasonally dry tropical forests. Cambridge University Press, New York.

Gerhardt, K. 1994. Seedling development of four tree species in secondary tropical dry forest in Guanacaste, Costa Rica. Comprehensive Summaries of Uppsala Dissertations from the Faculty of Science and Technology 39. Stockholm, Uppsala, Sweden.

Gerhardt, K. 1996a. Effects of root competition and canopy openness on survival and growth of tree seedlings in a tropical seasonal dry forest. Forest Ecology and Management 82:33-48.

Gerhardt, K. 1996b. Germination and development of sown mahogany (Swietenia macrophylla King) in secondary tropical dry forest habitats in Costa Rica. Journal of Tropical Ecology 12:275-289.

Gillespie, T. W. 1999. Life history characteristics and rarity of woody plants in tropical dry forest fragments of Central America. Journal of Tropical Ecology 15:637-649.

Gillespie, T. W., A. Grijalva, and C. N. Farris. 2000. Diversity, composition, and structure of tropical dry forests in Central America. Plant Ecology 147:37-47.
Gillison, A. N. 1983. Tropical savannas of Australia and the Southwest Pacific. Pages 183-243 in F. Bourlière, editor. Tropical savannas. Elsevier, Amsterdam, the Netherlands.

Goldammer, J. G. 1993. Fire management. Pages 1221-1265 in L. Pancel, editor. Tropical Forestry Handbook, Vol. 2. Springer-Verlag, Berlin, Germany.

Griz, L. M. S., and I. C. S. Machado. 2001. Fruiting phenology and seed dispersal syndromes in caatinga, a tropical dry forest in the Northeast of Brazil. Journal of Tropical Ecology 17:303-321.

Guariguata, M. R., J. J. Rosales Adame, and B. Finegan. 2000. Seed removal and fate in two selectively-logged lowland forests with contrasting protection levels. Conservation Biology 14:1046-1054.

Guarino, E. S. G. 2004. Germinação de sementes e estabelecimento de plântulas de árvores em florestas estacionais deciduais e pastagens abandonadas. Dissertation, Universidade de Brasília, Brasília, DF, Brazil.

Hammond, D. S. 1995. Postdispersal seed and seedling mortality of tropical dry forest trees after shifting agriculture, Chiapas, Mexico. Journal of Tropical Ecology 11:295-313.

Hardwick, K., J. Healey, S. Elliott, N. Garwood, and V. Anusarnsunthorn. 1997. Understanding and assisting natural regeneration processes in degraded seasonal evergreen forests in northern Thailand. Forest Ecology and Management 99:203-214.

Henery, M. L., and M. Westoby. 2001. Seed mass and seed nutrient content as predictors of seed output variation between species. Oikos 92:479-490.

Holdridge, L. R. 1967. Life zone ecology. Tropical Science Center, San Jose, Costa Rica.

Holl, K. D. 1999. Factors limiting tropical rain forest regeneration in abandoned pasture: seed rain, seed germination, microclimate, and soil. Biotropica 31:229-242.

Holl, K. D. 2002. Tropical moist forest. Pages 539-558 in M. Perrow and A. J. Davy, editors. Handbook of Ecological Restoration, Vol. II. Cambridge University Press, Cambridge, United Kingdom.

Holl, K. D., and M. E. Lulow. 1997. Effects of species, habitat, and distance from edge on post-dispersal seed predation in a tropical rainforest. Biotropica 29:459-468.

Holl, K. D., and E. Quiros-Nietzen. 1999. The effect of rabbit herbivory on reforestation of abandoned pasture in southern Costa Rica. Biological Conservation 87:391-395.

Holmgren, M., M. Scheffer, and M. A. Huston. 1997. The interplay of facilitation and competition in plant communities. Ecology 78: 1966-1975.

Honu, Y. A. K., and Q. L. Dang. 2000. Responses of tree seedlings to the removal of Chromolzena odorata Linn. in a degraded forest in China. Forest Ecology and Management 137:7582.

Honu, Y. A. K., and Q. L. Dang. 2002. Spatial distribution and species composition of tree seeds and seedlings under the canopy of the shrub, Chromolaena odorata Linn., in Ghana. Forest Ecology and Management 164:185-196.

Hopkins, B. 1992. Ecological processes at the forest-savanna boundary. Pages $21-33$ in P. A. Furley, J. Proctor, and J. A. Ratter, editors. Nature and dynamics of forest-savanna boundaries. Chapman \& Hall, London, United Kingdom.

Howe, H. F., and J. Smallwood. 1982. Ecology of seed dispersal. Annual Review of Ecology and Systematics 13:201-228.

Itoh, A., T. Yamakura, M. Kanzaki, T. Ohkubo, P. A. Palmiotto, J. V. LaFrankie, J. J. Kendawang, and H. S. Lee. 2002. Rooting ability of cuttings relates to phylogeny, habitat preference and growth characteristics of tropical rainforest trees. Forest Ecology and Management 168:275-287.

Janzen D. H. 1966. Synchronization of sexual reproduction of trees within the dry season in Central America. Evolution 21:620-637.

Janzen D. H. 1967. Synchronization of sexual reproduction of trees within dry season in Central America. Ecology 21:620-637. 
Janzen, D. H. 1981. Guanacaste tree seed-swallowing by Costa-Rican range horses. Ecology 62:587-592.

Janzen, D. H. 1988. Tropical dry forests, the most endangerous major tropical ecosystem. Pages 130-137 in E. O. Wilson, editor. Biodiversity. National Academy Press, Washington, D.C.

Janzen, D. H. 2002. Tropical dry forest: area de conservación Guanacaste, northwestern Costa Rica. Pages 559-583 in M. Perrow and A. J. Davy, editors. Handbook of Ecological Restoration, Vol. II. Cambridge University Press, Cambridge, United Kingdom.

Jones, F. A., C. J. Peterson, and B. L. Haines. 2003. Seed predation in neotropical pre-montane pastures: site, distance, and species effects. Biotropica 35:219-225.

Justiniano, M. J., and T. S. Fredericksen. 2000. Phenology of tree species in Bolivian dry forests. Biotropica 32:276-281.

Kammesheidt, L. 1999. Forest recovery by root suckers and above-ground sprouts after slash-and-burn agriculture, fire and logging in Paraguay and Venezuela. Journal of Tropical Ecology 15:143-157.

Kanowski, J., C. P. Catterall, and G. W. Wardell-Johnson. 2005. Consequences of broadscale timber plantations for biodiversity in cleared rainforest landscapes of tropical and subtropical Australia. Forest Ecology and Management 208:359-372.

Kanowski, J., C. P. Catterall, G. W. Wardell-Johnson, H. Proctor, and T. Reis. 2003. Development of forest structure on cleared rainforest land in eastern Australia under different styles of reforestation. Forest Ecology and Management 183:265-280.

Kennard, D. K. 2002. Secondary forest succession in a tropical dry forest: patterns of development across a 50-year chronosequence in lowland Bolivia. Journal of Tropical Ecology 18:53-66.

Kennard, D. K., K. Gould, F. E. Putz, T. S. Fredericksen, and F. Morales. 2002. Effect of disturbance intensity on regeneration mechanisms in a tropical dry forest. Forest Ecology and Management 162:197-208.

Khurana, E., and J. S. Singh. 2001. Ecology of seed and seedling growth for conservation and restoration of tropical dry forest: a review. Environmental Conservation 28:39-52.

Lai, P. C. C., and B. S. F. Wong. 2005. Effects of tree guards and weed mats on the establishment of native tree seedlings: implications for forest restoration in Hong Kong, China. Restoration Ecology 13:138-143.

Lieberman, D., and M. G. Li. 1992. Seedling recruitment patterns in a tropical dry forest in Ghana. Journal of Vegetation Science 3:375-382.

Marcano-Vega, H., T. M. Aide, and D. Baez. 2002. Forest regeneration in abandoned coffee plantations and pastures in the Cordillera Central of Puerto Rico. Plant Ecology 161:75-87.

Marod, D., U. Kutintara, H. Tanaka, and T. Nakashizuka. 2002. The effects of drought and fire on seed and seedling dynamics in a tropical seasonal forest in Thailand. Plant Ecology 161:41-57.

Marod, D., U. Kutintara, H. Tanaka, and T. Nakashizuka. 2004. Effects of drought and fire on seedling survival and growth under contrasting light conditions in a seasonal tropical forest. Journal of Vegetation Science 15:691-700.

McLaren, K. P., and M. A. McDonald. 2003a. Seedling dynamics after different intensities of human disturbance in a tropical dry limestone forest in Jamaica. Journal of Tropical Ecology 19:567-578.

McLaren, K. P., and M. A. McDonald. 2003b. The effects of moisture and shade on seed germination and seedling survival in a tropical dry forest in Jamaica. Forest Ecology and Management 183:61-75.

McLaren, K. P., and M. A. McDonald. 2003c. Coppice regrowth in a disturbed tropical dry limestone forest in Jamaica. Forest Ecology and Management 180:99-111.

Meiners, S. J., and K. LoGiudice. 2003. Temporal consistency in the spatial pattern of seed predation across a forest-old field edge. Plant Ecology 168:45-55.

Meli, P. 2003. Restauración ecológica de bosques tropicales. Veinte años de investigación académica. Interciencia 28:581-589.

Menaut, J. C., M. Lepage, and L. Abbadie. 1995. Savannas, woodlands and dry forests in Africa. Pages 64-92 in S. H. Bullock, H. A. Mooney, and E. Medina, editors. Seasonally dry tropical forests. Cambridge University Press, New York.

Miller, P. M. 1999. Effects of deforestation on seed banks in a tropical deciduous forest of western Mexico. Journal of Tropical Ecology 15:179-188.

Miller, P. M., and J. B. Kauffman. 1998. Seedling and sprout response to slash-and-burn agriculture in a tropical deciduous forest. Biotropica 30:538-546.

Mooney, H. A., S. H. Bullock, and E. Medina. 1995. Introduction. Pages 1-8 in S. H. Bullock, H. A. Mooney, and E. Medina, editors. Seasonally dry tropical forests. Cambridge University Press, New York.

Morellato, L. P. C., D. C. Talora, A. Takahasi, C. C. Bencke, E. C. Romera, and V. B. Zipparro. 2000. Phenology of Atlantic rain forest trees: a comparative study. Biotropica 32:811-823.

Murphy, P. G., and A. E. Lugo. 1986. Ecology of tropical dry forest. Annual Review of Ecology and Systematics 17:67-88.

Murphy, P. G., and A. E. Lugo. 1995. Dry forests of Central America and Caribbean islands. Pages 9-34 in S. H. Bullock, H. A. Mooney, and E. Medina, editors. Seasonally dry tropical forests. Cambridge University Press, New York.

Nepstad, D. C., C. Uhl, C. A. Pereira, and J. M. C. Silva. 1996. A comparative study of tree establishment in abandoned pasture and mature forest of eastern Amazonia. Oikos 76:25-39.

Nepstad, D. C., C. Uhl, and E. A. S. Serrao. 1990. Surmounting barriers to forest regeneration in abandoned, highly degraded pastures: a case study from Paragominas, Pará, Brazil. Pages 215-229 in A. B. Anderson, editor. Alternatives to deforestation: steps toward sustainable use of the Amazon rain forest. Columbia University Press, New York.

Osunkoya, O. O. 1994. Postdispersal survivorship of North Queensland rainforest seeds and fruits: effects of forest, habitat and species. Australian Journal of Ecology 19:52-64.

Osunkoya, O. O., J. E. Ash, M. S. Hopkins, and A. W. Graham. 1992. Factors affecting survival of tree seedlings in North Queensland rainforests. Oecologia 91:569-578.

Otsamo, R. 2000. Early development of three planted indigenous tree species and natural understorey vegetation in artificial gaps in an Acacia mangium stand on an Imperata cylindrica grassland site in South Kalimantan, Indonesia. New Forests 19:51-68.

Pariona, W., T. S. Fredericksen, and J. C. Licona. 2003. Natural regeneration and liberation of timber species in logging gaps in two Bolivian tropical forests. Forest Ecology and Management 181:313322.

Parrotta, J. A., and O. H. Knowles. 1999. Restoration of tropical moist forest on degraded bauxite mined lands in the Brazilian Amazon. Restoration Ecology 7:103-116.

Parrotta, J. A. 1995. Influence of overstory composition on understory colonization by native species in plantations on a degraded tropical site. Journal of Vegetation Science 6:627-636.

Peña-Claros, M., and H. De Boo. 2002. The effect of forest successional stage on seed removal of tropical rain forest tree species. Journal of Tropical Ecology 18:261-274.

Pennington, R. T., D. E. Prado, and C. A. Pendry. 2000. Neotropical seasonally dry forests and Quaternary vegetation changes. Journal of Biogeography 27:261-273.

Pinard, M. A., F. E. Putz, D. Rumíz, R. Guzmán, and A. Jardim. 1999. Ecological characterization of tree species for guiding forest management decisions in seazonally dry forests in Lomerío, Bolivia. Forest Ecology and Management 131:201-213.

Posada, J. M., T. M. Aide, and J. Cavelier. 2000. Cattle and weedy shrubs as restoration tools of tropical montane rainforest. Restoration Ecology 8:370-379.

Price, M. V. and S. H. Jenkins. 1986. Rodents as seed consumers and dispersers. Pages 191-235 in D. R. Murray, editor. Seed dispersal. Academic Press, Sidney, Australia. 
Ray, G. J., and B. J. Brown. 1995. Restoring Caribbean dry forests: evaluation of tree propagation techniques. Restoration Ecology 3:86-94.

Rincon, E., and P. Huante. 1993. Growth responses of tropical deciduous tree seedlings to contrasting light conditions. Trees-Structure and Function 7:202-207.

Rundel, P. W., and K. Boonpragob. 1995. Dry forests ecosystems in Thailand. Pages $93-123$ in S. H. Bullock, H. A. Mooney, and E. Medina, editors. Seasonally dry tropical forests. Cambridge University Press, New York.

Russell-Smith, J. 1996. Regeneration of monsoon rain forest in northern Australia: the sapling bank. Journal of Vegetation Science 7:889-900.

Sabogal, C. 1992. Regeneration of tropical dry forests in Central-America, with examples from Nicaragua. Journal of Vegetation Science 3: 407-416.

Saha, S., and H. F. Howe. 2003. Species composition and fire in a dry deciduous forest. Ecology 84:3118-3123.

Sampaio, E. 1995. Overview of the Brazilian caatinga. Pages 35-63 in S. H. Bullock, H. A. Mooney, and E. Medina, editors. Seasonally dry tropical forests. Cambridge University Press, New York.

Sampaio, E., I. H. Salcedo, and J. B. Kauffman. 1993. Effect of different fire severities on coppicing of caatinga vegetation in Serra Talhada, Pe, Brazil. Biotropica 25:452-460.

Sanchez-Azofeifa, G. A., M. Kalacska, M. Quesada, J. C. Calvo-Alvarado, J. M. Nassar, and J. P. Rodríguez. 2005. Need for integrated research for a sustainable future in tropical dry forests. Conservation Biology 19:285-286.

Scariot, A., and A. C. Sevilha. 2000. Diversidade, estrutura e manejo de florestas deciduais e as estratégias para a conservação. Pages 183188 in T. B. Cavalcanti and B. M. T. Walter, editors. Tópicos atuais em botânica: palestras convidadas do $51^{\circ}$ Congresso Nacional de Botânica. Embrapa Recursos Genéticos e Biotecnologia, Brasília.

Singh, J. S., and V. K. Singh. 1992. Phenology of seasonally dry tropical forest. Current Science 63:684-689.

Skoglund, J. 1992. The role of seed banks in vegetation dynamics and restoration of dry tropical ecosystems. Journal of Vegetation Science 3:357-360.

Slocum, M. G., and C. C. Horvitz. 2000. Seed arrival under different genera of trees in a neotropical pasture. Plant Ecology 149:5162.

Souza, R. P., and I. F. M. Válio. 2001. Seed size, seed germination, and seedling survival of Brazilian tropical tree species differing in successional status. Biotropica 33:447-457.

Sun, D., and G. R. Dickinson. 1996. The competition effect of Brachiaria decumbens on the early growth of direct-seeded trees of Alphitonia petriei in tropical North Australia. Biotropica 28:272-276.

Sun, D., G. R. Dickinson, and A. L. Bragg. 1995. Direct seeding of Alphitonia petriei (Rhamnaceae) for gully revegetation in tropical northern Australia. Forest Ecology and Management 73:249-257.
Swaine, M. D. 1992. Characteristics of dry forest in West Africa and the influence of fire. Journal of Vegetation Science 3:365-374.

Teketay, D., and A. Granstrom. 1995. Soil seed banks in dry Afromontane forests of Ethiopia. Journal of Vegetation Science 6:777-786.

Toh, I., M. Gillespie, and D. Lamb. 1999. The role of isolated trees in facilitating tree seedling recruitment at a degraded sub-tropical rainforest site. Restoration Ecology 7:288-297.

Uhl, C., R. Buschbacher, and E. A. S. Serrao. 1988. Abandoned pastures in eastern Amazonia. I. Patterns of plant succession. Journal of Ecology 76:663-681.

Vázquez-Yanes, C., and A. Orozco-Segovia. 1993. Patterns of seed longevity and germination in the tropical rain forest. Annual Review of Ecology and Systematics 24:69-87.

Vesk, P. A., and M. Westoby. 2004. Sprouting ability across diverse disturbances and vegetation types worldwide. Journal of Ecology 92:310-320.

Viana, V. M., A. A. J. Tabanez, and J. L. F. Batista. 1997. Dynamics and restoration of forest fragments in the Brazilian Atlantic moist forest. Pages 351-355 in W. F. Laurance and R. O. J. Bierregard, editors. Tropical forest remnants. The University of Chicago Press.

Vieira, D. L. M. 2002. Efeitos da exploração madeireira na estrutura e regeneração de populações de árvores de floresta estacional decidual. Dissertation, Universidade de Brasília, Brasília, Brazil.

Vieira, D. L., M., A. Scariot, A. B. Sampaio, and K. D. Holl. In press. Tropical dry-forest regeneration from root suckers in Central Brazil. Journal of Tropical Ecology. 177:249-257.

Xiao, Z. S., Z. B. Zhang, and Y. S. Wang. 2005. The effects of seed abundance on seed predation and dispersal by rodents in Castanopsis fargesii (Fagaceae). Plant Ecology 177:249-257.

Westoby, M., D. S. Falster, A. T. Moles, P. A. Vesk, and I. J. Wright. 2002. Plant ecological strategies: some leading dimensions of variation between species. Annual Review of Ecology and Systematics 33:125-159.

Westoby, M., M. Leishman, and J. Lord. 1996. Comparative ecology of seed size and dispersal. Philosophical Transactions of the Royal Society of London. Series B, Biological Sciences 351:1309-1317.

Willson, M. F., and F. H. J. Crome. 1989. Patterns of seed rain at the edge of a tropical Queensland rain-forest. Journal of Tropical Ecology 5:301-308.

Woods, K., and S. Elliott. 2004. Direct seeding for forest restoration on abandoned agricultural land in northern Thailand. Journal of Tropical Forest Science 16:248-259.

Zahawi, R. A. 2005. Establishment and growth of living fence species: an overlooked tool for the restoration of degraded areas in the tropics. Restoration Ecology 13:92-102.

Zimmerman, J. K., J. B. Pascarella, and T. M. Aide. 2000. Barriers to forest regeneration in an abandoned pasture in Puerto Rico. Restoration Ecology 8:350-360. 